\title{
CORRIGENDA/ERRATUM
}

\section{International uniform response criteria for multiple myeloma}

BGM Durie ${ }^{1}$, J-L Harousseau ${ }^{2}$, JS Miguel ${ }^{3}$, J Bladé ${ }^{4}$, B Barlogie $^{5}$, K Anderson $^{6}$, M Gertz $^{7}$, M Dimopoulos $^{8}$, J Westin $^{9}$, P Sonneveld $^{10}$,

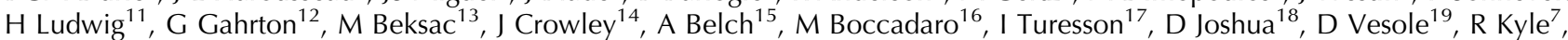
R Alexanian ${ }^{20}$, G Tricot ${ }^{5}, \mathrm{M} \mathrm{Attal}{ }^{21}, \mathrm{G} \mathrm{Merlini}^{22}, \mathrm{R} \mathrm{Powles}^{23}, \mathrm{P}$ Richardson $^{24}, \mathrm{~K} \mathrm{Shimizu}^{25}, \mathrm{P} \mathrm{Tosi}^{26}, \mathrm{G} \mathrm{Morgan}^{27}$ and SV Rajkumar $^{7}$, on behalf of the International Myeloma Working Group ${ }^{29}$

Leukemia (2007) 21, 1134. doi:10.1038/sj.leu.2404582

Correction to: Leukemia (2006) 20, 1467-1473. doi:10.1038/ sj.leu.2404284

It has been identified by the authors that there are three errors in this paper.

Table 4: Criteria listed under subheading 'Definitions for measurable disease' should also include:

'Bone marrow plasma cells $\geqslant 30 \%$.
Table 5: Bone marrow criteria for $\mathrm{CR}$ should be ' $<5 \%$ plasma cells' and not ' $\leqslant 5 \%$ plasma cells'.

Table 6: Relapse criteria for progressive disease should state 'Increase of $\geqslant 25 \%$ from lowest response level' and not 'Increase of $\geqslant 25 \%$ from baseline'.

The authors apologize for these errors.

\section{Simultaneous detection of NPM1 and FLT3-ITD mutations by capillary electrophoresis in acute myeloid leukemia}

NI Noguera, E Ammatuna, D Zangrilli, S Lavorgna, M Divona, F Buccisano, S Amadori, C Mecucci, B Falini and F Lo-Coco

Leukemia (2007) 21, 1134. doi:10.1038/sj.leu.2404664

Correction to: Leukemia (2005) 19, 1479-1482.

doi:10.1038/sj.leu.2403846

It has been identified by the authors that there is an error in the sequence of primers used for FLT3 amplification (Table 1).
The correct sequence is as follows:

The authors apologize for any inconvenience caused.

Table 1

\begin{tabular}{|c|c|c|c|c|c|}
\hline Name & Sequence & Dye & Position & Accession number & PCR (product size) \\
\hline $\begin{array}{l}\text { (D3)ITD-R6 } \\
\text { R5-ITD }\end{array}$ & $\begin{array}{l}5^{\prime} \text {-atcctagtaccttcccaaactc-3' } \\
5^{\prime} \text {-tgtcgagcagtactctaaaca- } 3^{\prime}\end{array}$ & D3 & $\begin{array}{l}1913-1934 \\
1569-1589\end{array}$ & $\begin{array}{l}\text { NM_004119 } \\
\text { NM_004119 }\end{array}$ & Flt3-ITD (366 bp) \\
\hline
\end{tabular}

